التثخيص السيرولجي لداء المقوسات بواسطة استخدام الاجسام المضادة الخاصة في الجمال في

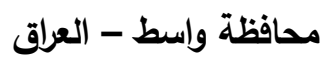

م.د باسم محمد حنون

فرع الاحياء المجهرية/ كلية الطب البيطري/ جامعة واسط

الخلاصة

الخلفية: توكسوبلاسما غونديي هو الطفيلي مشترك ،بلاضافة الى ذالك يعتبر مشكلة كبيرة للصحة

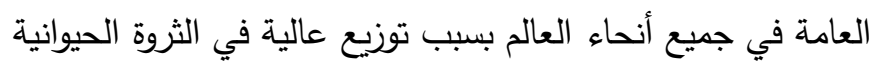

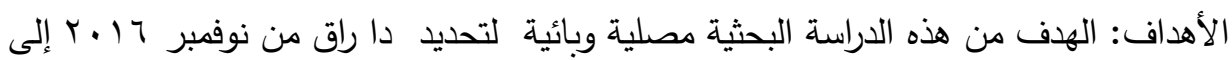

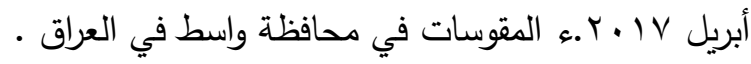

المواد وطرق العمل : عينات الدم التي تم جمعها عشوائيا من ستة مجموعات مختلفة من الحيوانات

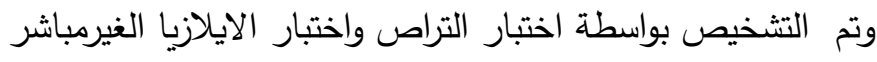

النتائج: تم تسجيل انتشار شامل للعدوى بطفيلي توكسوبلاسما غونديي ، وكانت العينات الموجبة

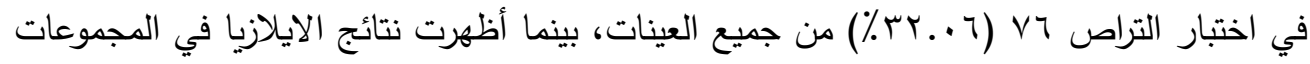

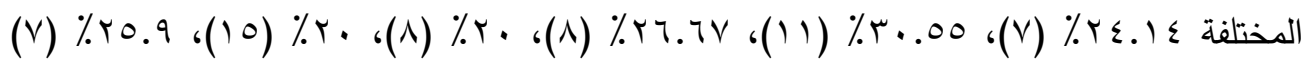

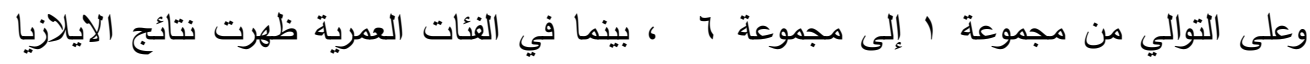

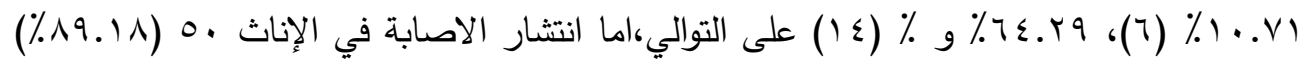

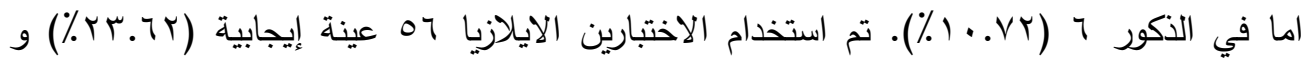

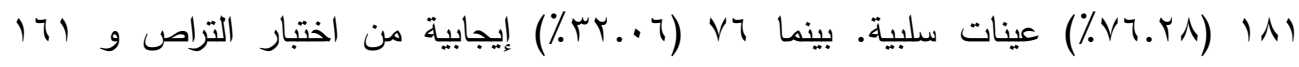

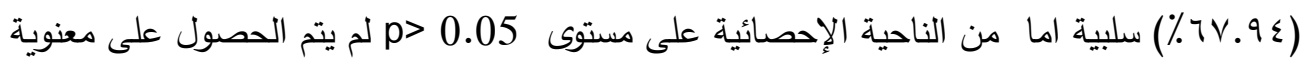
في الإصابة بين مجموعات الجمال الستة. الاستنتاجات: أظهرت النتائج أيضا أن هذه الحيوانات هي المصدر الرئيسي للعدوى البشرية.العدوى

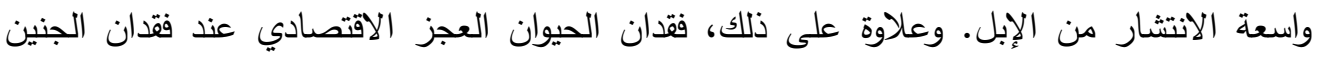

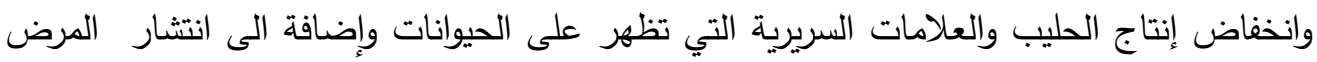
الى الانسان في المناطق النقاب المصابة. 


\section{Serological diagnosis of Toxoplasmosis by specific antibody in camels of Wasit province, Iraq}

\section{Basim Mohammed Hanon}

Department of Microbiology, college of Veterinary Medicine, Wasit University, Iraq

\section{basimhanon@gmail.com}

Background: toxoplasma gondii is a zoonotic parasite, more added a major public health is worldwide because have high distribution in livestock.

Objectives: the main aim of this study determine the occurrence of the seroepidemiological toxoplasmosis in camels in waist province of Iraq from November 2016 to April 2017.

Materials and Methods: blood samples collected of animals randomly were included six different groups of animals were diagnosed by A Latex agglutination test (LAT) and indirect enzyme linked immunosorbent assay (ELISA) kits.

Results: An overall prevalence of T. gondii infections were recorded, the positive sample with LAT test was $76(32.06 \%)$ from all sample, the results of ELISA was shown in different groups $24.14 \%$ (7), $30.55 \%$ (11), $26.67 \%$ (8), $20 \%(8), 20 \%$ (15), $25.9 \%$ (7) group1 to group 6 respectively, while in age groups ELISA results was appeared $10.71 \%$ (6) , 64.29\% (36) and 25\% (14) respectively, the serprevalence in females $50(89.18 \%)$ and positive in males $6(10.72 \%)$. the two tests was used ELISA 56 positive samples (23.62\%) and 181(76.28\%) negative samples. But 76 (32.06\%) positive by LAT test and 161(67.94\%) negative.

Statically in $p>0.05$ no significant was obtained in infection between groups of camels in this study and between the sex in all camels groups.

Conclusions: Also high seroprevalence of Toxoplasma gondii in studied camles indicated the importance of these animals as the main source of human infection. The widespread infection of camels. Furthermore, animal loss the economic impotent when loss of fetus and decrease milk production and clinical signs that appears on animals and adding zoonotic effect in the area study.

Keywords: Serum; latex agglutination; ELISA, Camels; Toxoplasma; Iraq 


\section{Introduction}

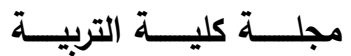

The toxoplasmosis worldwide diseases of mammals including human and birds which infects nucleated cells (1) all types of domestic livestock (camels' sheep and goats, wildlife, companion animals) The oocysts felids disseminate into environment considered of sours of infection (2). Losses of fetus due to abortion responsible for toxoplasmosis infection the impotent economic effected. (3) Reproductive failure of Infection a high risk to public health. (4)

All mammalian can become infected with toxoplasmosis by taking catoocysts that contaminated water, soil, food or ingesting raw undercooked meat containing tissue cysts. Toxoplasmosis causes congenital disease include abortion and more common parasitic zoonosis. (5-7) The accidental ingestion of oocysts, the intermediate hosts get the infected through shed cats oocysts. Transmission accrues by transplacental in case of camels' goat, and sheep. (8) When Toxoplasma gondii infection individual the immune response complex and compartment, heterogeneity in genetic background causes the individual variation at severity of diseases (9).

Central nervous system CNS and placenta is a Specific immune response, in addition, ability to reach in different tissues and each tissue closet has its own. An additional some strains of Toxoplasma causes recurrent with virulence the degree of complexity due to the possibility (10). Subclinical infection vast majority of infections in livestock camels' sheep and goats. Generally non-specific clinical signs are present, and may have a period of respiratory disorder, anorexia, fever and diarrhea. (11) Increased risk of transmission accrues when Contact and interaction between livestock and humans are ability for infection by toxoplasmosis (12). Camels play an impotent role in economic sources through provision of milk, meat and leather industry (13), (14). There are many testing methods to diagnose of infection. The good diagnostic or testing methods enhances prevention and control of the toxoplasmosis, effective control and prevention of T. gondii require appropriate for the virulence strain and specific species. (15) The aim of current study was determine the seroprevalence Toxoplasma gondii in livestock of camels in waste province of Iraq. 
العــــــدد التاسع والعشرون

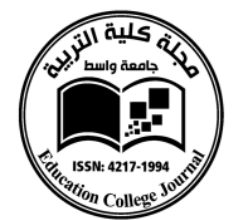

Materials and methods

Study area

The present area of study in the eastern region of wasite provinces Iraq, this area contain the natural pastures that enhances the grazing of camels in the area between $\left(32^{\circ} 29^{\prime} 38.86^{\prime \prime} \mathrm{N} 45^{\circ} 48^{\prime} 51.7^{\prime \prime} \mathrm{E}\right.$. Almost the animals grazing in rural areas and contacts with different animals livestock.

\section{Blood samples}

The study which include collection two hundred and thirty seven blood samples (209 females \&28 males) these samples were collected from November 2016 to April -2017, from puncture of jugular vein from each animal and transferred to laboratory, the collected in tubes without anticoagulant and give a specific cods of each sample, at 3000 r.p.m. for 10 minutes samples were centrifuged. Serum were separated and pickup in (1.5 $\mathrm{ml}$ ) eppendorf tubes, samples stored deep freezing for further analysis. All these samples collected randomly from different herds' animals, the range age (1-15years).

\section{Serological examination \\ Latex agglutination test}

TOXO-Latex ® Spain Latex agglutination test (SPINRER EACT, S. A. Ctra. Santa Coloma) basically was used to screen the serum. Polystyrene latex particles in the reagent was coated with soluble $T$. gondii antigen. Antigen-antibody reaction enhance visual observe particles.

The serum and the antigens were mixed on the entire circle of the plate with a stirrer over its. For 4-6 minutes the plate, the reading was recoded immediately after end time. When visible agglutination was this result positive, when not agglutination the antibody not present in the serum no reaction (negative). The test procedure depend on manufacturer's protocol.

\section{(ELISA) Enzyme-linked immunosorbent assay}

On the other hand, the indirect ELISA (ID. VET. Innovative diagnostics, France) was also used for the diagnosis of IgG anti-Toxoplasma antibodies with anti- $T$. gondii ELISA. Depend on the manufacturer's instructions antibody titer were estimate by following on the set at the laboratory. The commercial kit of ELISA was used. The reading of results in instrument depend on $450 \mathrm{~nm}$ Optical densities (OD). The test procedure was carried out as per the manufacturer's protocol 


\section{Data statistical analysis}

Analyze the data was used to Social sciences (SPSS) version 12.0 All data were using computer and statistically significant a $p$-value less than 0.05 .

\section{Results}

Seroprevalence of $\mathbf{T}$ gondii by LAT and ELISA test:

In this study collected three hander thirty seven samples these samples were collected randomly from six herds camels in Wasit province from different localities: (29 (group1), 30 f (group 2), 36 (group 3), 40 (group 4). 75 (group 5) and 27 (group 6) Table (1-6). From all sample 209 females and 28 males and divided into three age ( 1 to 5years) 31 , (5 to 10 years) 140 and (more than 10 years) 66 . The positive sample with LAT test was 76 (32.06\%) from all sample.

A total of 76 positive by latex from sex locals herd in study confirmed by ELISA from $56(23.62 \%)$ positive from 76 positive by LAT, this result follows: $24.14 \%$ (7), $30.55 \%$ (11), $26.67 \%$ (8), $20 \%$ (8), $20 \%$ (15), $25.9 \%$ (7) group1 to group 6 respectively table (7).

\section{Seroprevalence depend Age classification:}

Out of 237 samples tested classified depend on age groups follows: (1- 5) years72, (5-10) years 36, (more than 10)years 24, ELISA results of test in camels age groups $10.71 \%$ (6) , 64.29\% (36), 25\% (14) respectively. The serprevalences among the age there was no significant differences in table (8).

\section{Seroprevalence in different Sex:}

From out of all samples 237samples 207 females and 28 males, the positive females $50(89.18 \%)$ and positive in males $6(10.72 \%)$, the serprevalence between females and males were significantly different.

Comparison of latex agglutination test (LAT) \& ELISA test for detection of positive serum samples from camels

The samples 237 collected $76(32.06 \%)$ sera were positive and $161(67.94 \%)$ negative to LAT detection of antibodies (IgG) depended the protocol of the manufacturer while Indirect (ELISA) 56 positive samples $(23.62 \%)$ and $181(76.28 \%)$ negative samples tested antibodies by the 
indirect ELISA kit protocol. The sensitivity, specificity for both test was calculated as $\mathrm{P}=(0.04)$.

Table 1:- Seroprevelence of T.gondii IgG antibody at ELISA in group 1

\begin{tabular}{|l|l|l|l|l|l|l|l|}
\hline $\begin{array}{l}\text { Farm } \\
1(29)\end{array}$ & $\begin{array}{l}1 \text { to } 5 \\
\mathrm{y}\end{array}$ & $\begin{array}{l}5 \\
10 \mathrm{y}\end{array}$ & $\begin{array}{l}\text { More } \\
10 \mathrm{y}\end{array}$ & Total & $\%$ & P-value & Chi \\
\hline No. & 3 & 22 & 4 & 29 & & & \\
\hline Male & 1 & 1 & $/$ & 2 & $6.9 \%$ & $00000^{*}$ & 1.500 \\
\hline female & 2 & 21 & 4 & 27 & $93.1 \%$ & $0.0002^{*}$ & 36.333 \\
\hline Positive & 1 & 5 & 1 & 7 & $24.14 \%$ & 0.032 & 6.857 \\
\hline Negative & 2 & 17 & 3 & 22 & $75.86 \%$ & $0.0002^{*}$ & 28.773 \\
\hline
\end{tabular}

Table 2:- Seroprevelence of T.gondii IgG antibody at ELISA in group 2

\begin{tabular}{|l|l|l|l|l|l|l|l|}
\hline Farm2 (36) & $\begin{array}{l}1 \text { to } 5 \\
\mathrm{y}\end{array}$ & $\begin{array}{l}5 \\
10 \mathrm{y}\end{array}$ & $\begin{array}{l}\text { More } 10 \\
\mathrm{y}\end{array}$ & Total & $\%$ & $\begin{array}{l}\text { P- } \\
\text { value }\end{array}$ & Chi \\
\hline No. & 9 & 19 & 8 & 36 & & & \\
\hline Male & 3 & 3 & $/$ & 6 & $\begin{array}{l}16.66 \\
\%\end{array}$ & 0.105 & $\begin{array}{l}4.50 \\
0\end{array}$ \\
\hline Female & 6 & 16 & 8 & 30 & $\begin{array}{l}83.34 \\
\%\end{array}$ & $0.015^{*}$ & $\begin{array}{l}8.40 \\
0\end{array}$ \\
\hline Positive & 2 & 8 & 1 & 11 & $\begin{array}{l}30.55 \\
\%\end{array}$ & $0.003^{*}$ & $\begin{array}{l}11.7 \\
27\end{array}$ \\
\hline Negative & 7 & 11 & 7 & 25 & $\begin{array}{l}69.45 \\
\%\end{array}$ & 0.383 & $\begin{array}{l}1.92 \\
0\end{array}$ \\
\hline
\end{tabular}

Table 3:- Seroprevelence of by T.gondii IgG antibody at ELISA in group 3.

\begin{tabular}{|l|l|l|l|l|l|l|l|}
\hline $\begin{array}{l}\text { Farm3 } \\
(30)\end{array}$ & $\begin{array}{l}1 \text { to } 5 \\
\mathrm{y}\end{array}$ & $\begin{array}{l}5 \\
10 \mathrm{y}\end{array}$ & $\begin{array}{l}\text { More } 10 \\
\mathrm{y}\end{array}$ & Total & $\%$ & $\begin{array}{l}\text { P- } \\
\text { value }\end{array}$ & Chi \\
\hline No. & 3 & 17 & 10 & 30 & & & \\
\hline Male & $/$ & 2 & 2 & 4 & $13.34 \%$ & 0.223 & 3.000 \\
\hline Female & 3 & 15 & 8 & 26 & $86.6 \%$ & $0.002^{*}$ & 12.577 \\
\hline Positive & $/$ & 4 & 4 & 8 & $26.67 \%$ & $0.050^{*}$ & 6.000 \\
\hline Negative & 3 & 13 & 6 & 22 & $73.33 \%$ & $0.005^{*}$ & 10.773 \\
\hline & & & & & & & \\
\hline
\end{tabular}


Table 4:- Seroprevelence of by T.gondii IgG antibody at ELISA in group 4.

\begin{tabular}{|c|c|c|c|c|c|c|c|}
\hline $\begin{array}{l}\text { Farm } 4 \\
(40)\end{array}$ & $\begin{array}{l}1 \text { to } 5 \\
y\end{array}$ & $\begin{array}{l}5 \quad- \\
10 y\end{array}$ & $\begin{array}{l}\text { More } 10 \\
\mathrm{y}\end{array}$ & Total & $\%$ & P-value & Chi \\
\hline No. & 5 & 22 & 13 & 40 & & & \\
\hline Male & 1 & 2 & 1 & 4 & $10 \%$ & 0.687 & 0.750 \\
\hline Female & 4 & 20 & 12 & 36 & $90 \%$ & $0.0002 *$ & $\begin{array}{l}16.00 \\
0\end{array}$ \\
\hline Positive & 1 & 5 & 2 & 8 & $20 \%$ & 0.087 & 4.875 \\
\hline Negative & 4 & 17 & 11 & 32 & $80 \%$ & $0.003 *$ & $\begin{array}{l}11.90 \\
6\end{array}$ \\
\hline
\end{tabular}

Table 5:- Seroprevelence of by T.gondii IgG antibody at ELISA in group 5

\begin{tabular}{|l|l|l|l|l|l|l|l|}
\hline $\begin{array}{l}\text { Farm } \\
(75)\end{array}$ & $\begin{array}{l}1 \text { to } 5 \\
\mathrm{y}\end{array}$ & $\begin{array}{l}5- \\
10 \mathrm{y}\end{array}$ & $\begin{array}{l}\text { More } 10 \\
\mathrm{y}\end{array}$ & Total & $\%$ & P-value & Chi \\
\hline No. & 8 & 40 & 27 & 75 & & & \\
\hline Male & 2 & 4 & 3 & 9 & $12 \%$ & 0.607 & 1.000 \\
\hline Female & 6 & 36 & 24 & 66 & $88 \%$ & $0.0003^{*}$ & 31.091 \\
\hline Positive & 1 & 9 & 5 & 15 & $20 \%$ & $0.008^{*}$ & 9.600 \\
\hline Negative & 7 & 31 & 22 & 60 & $80 \%$ & $0.003^{*}$ & 11.982 \\
\hline & & & & & & & \\
\hline
\end{tabular}

Table 6:- Seroprevelence of by T.gondii IgG antibody at ELISA in group 6

\begin{tabular}{|l|l|l|l|l|l|l|l|}
\hline $\begin{array}{l}\text { Farm } \\
(27)\end{array}$ & $\begin{array}{l}1 \text { to } \\
5 \mathrm{y}\end{array}$ & $\begin{array}{l}5 \\
10 \\
\mathrm{y}\end{array}$ & $\begin{array}{l}\text { More } \\
10 \mathrm{y}\end{array}$ & Total & $\%$ & P-value & Chi \\
\hline No. & 3 & 20 & 4 & 27 & & & \\
\hline Male & $/$ & 2 & 1 & 3 & $11.11 \%$ & 0.223 & 3.000 \\
\hline Female & 3 & 18 & 3 & 24 & $88.89 \%$ & $0.0001 *$ & 28.125 \\
\hline Positive & 1 & 5 & 1 & 7 & $25.9 \%$ & $0.032 *$ & 6.857 \\
\hline Negative & 2 & 15 & 3 & 20 & $74.1 \%$ & $0.0003 *$ & 23.550 \\
\hline
\end{tabular}


Table 7:- Seroprevelence of Toxoplasma gondii all groups of camels by using ELISA

\begin{tabular}{|l|l|l|l|l|l|l|l|}
\hline $\begin{array}{l}\text { Type of } \\
\text { test }\end{array}$ & G. 1 & G. 2 & G. 3 & G. 4 & G. 5 & G. 6 & Total \\
\hline No & 7 & 11 & 8 & 8 & 15 & 7 & 56 \\
\hline $\begin{array}{l}\text { Total \% } \\
\text { positive }\end{array}$ & $24.14 \%$ & $\begin{array}{l}30.55 \\
\%\end{array}$ & $\begin{array}{l}26.67 \\
\%\end{array}$ & $20 \%$ & $20 \%$ & $25.9 \%$ & $23.62 \%$ \\
\hline No & 22 & 25 & 22 & 32 & 60 & 20 & 181 \\
\hline $\begin{array}{l}\text { Total \% } \\
\text { negative }\end{array}$ & $75.86 \%$ & $\begin{array}{l}69.45 \\
\%\end{array}$ & $\begin{array}{l}73.33 \\
\%\end{array}$ & $80 \%$ & $80 \%$ & $74.1 \%$ & $76.38 \%$ \\
\hline & & & & $\begin{array}{l}\mathrm{P}= \\
0.845\end{array}$ & $\begin{array}{l}\mathrm{X} 2= \\
2.033\end{array}$ \\
\hline
\end{tabular}

Table 7:- Positive samples to Toxoplasma gondii at ELISA positive serum samples in difference age groups camels.

\begin{tabular}{|l|l|l|l|l|}
\hline No $(237)$ & $1-5 \mathrm{y}$ & $5-10 \mathrm{y}$ & More than 10 & Total \\
\hline Positive & 6 & 36 & 14 & 56 \\
\hline & $10.71 \%$ & $64.29 \%$ & $25 \%$ & \\
\hline Negative & 25 & 104 & 52 & 181 \\
\hline & $13.81 \%$ & $57.46 \%$ & $28.73 \%$ & \\
\hline & 31 & 140 & 66 & 237 \\
\hline & & P-value 0.649 & Chi 0.865 & \\
\hline
\end{tabular}

Table 8:- Positive samples to Toxoplasma gondii at ELISA positive serum samples in male and female camels.

\begin{tabular}{|l|l|l|l|l|l|l|l|}
\hline No (237) & $\begin{array}{l}1-5 \\
\mathrm{y}\end{array}$ & $\begin{array}{l}5-10 \\
\mathrm{y}\end{array}$ & $\begin{array}{l}\text { More } 10 \\
\mathrm{y}\end{array}$ & $\begin{array}{l}\text { Tota } \\
1\end{array}$ & $\%$ & chi & P vlaue \\
\hline Positive & 6 & 36 & 14 & 56 & & & \\
\hline $\begin{array}{l}\text { Male } \\
(28)\end{array}$ & 1 & 3 & 2 & 6 & 10.72 & 1.500 & 0.472 \\
\hline $\begin{array}{l}\text { Female } \\
(209)\end{array}$ & 5 & 30 & 12 & 50 & 89.28 & 38.220 & $0.0015^{*}$ \\
\hline
\end{tabular}


Table 9:- Sensitivity and specificity between two test of latex agglutination test (LAT) \& ELISA test

\begin{tabular}{|l|l|l|}
\hline Test & Positive & Negative \\
\hline LTEX positive & 76 & 161 \\
\hline$\%$ & 32.06 & 67.94 \\
\hline ELISA test & 56 & 181 \\
\hline$\%$ & 23.62 & 76.38 \\
\hline & Chi $=24.200$ & $\begin{array}{l}\mathrm{P} \text { value }= \\
0.040 *\end{array}$ \\
\hline
\end{tabular}

\section{Discussion}

The susceptibility to infection may be explained differences in occurrence of infection in domestic animal species (16), this defer depend on the susceptible of breed or sex, generally the rates of infection depend on methods of diagnosis used (16).

In this study LAT test was recorded $76(32.06 \%)$ while in ELISA test showed $56(23.62 \%)$. Some different study of Toxoplasmosis prevalence in Iraq refers to widespread infection in camels, with

different infection rate in 1998 in study of (17), 6.04\%, while $16.35 \%$ (18) in 2006 and $20.34 \%$ recorded by (19) in 2012.

УELISA test showed that 15 (16.4 \%), Using LAT, out of 360 serum samples $91(25.2 \%)(20)$.

On other different study, the toxoplasmosis incidence compared with our results, the prevalence in Sudan 20\% (21), and in Turkey $90.9 \%$ by using (22), another study in Egypt recorded 30.7\% (23). More study in Saudi Arabia rate of $13.6 \%$ have been detected in 2012 (24). While the reported seropositivity for toxoplasmosis in camel with percent of $6.5 \%$ (25). Furthermore 4\% infection rate with Toxoplasmosis were registered in Iran in 2006 (26). Iran (14.57\%) by using LAT (27). The different condition of animals included environmental factors husbandry system, and management practices reveal the different percentage of infection. (28). The ingestion with contamination food and water or inhalation of oocysts that are deduct by cats in the environment, it is conceivable exposure that the longer an animal lives, the greater the chance Toxoplasma infection by animals (29). Using LAT and ELISA assays in determine the incidence of toxoplasmosis 
antibody in infected animals serum, when detection of IgM seroprevalence sever case who able to transmission the oocyst to another farm animals, reflects the risk among animals with a recent infection, as in the contagious stage of the infection the animals, tachyzoites appeared in all fluids of body including milk (30). The detection nonspecific antibodies by LAT for T.gondii (cross reacted with other microorganisim) was used ELISA to test definitive diagnosis of positive samples with specific detection of only $\operatorname{IgG}$ antibodies or IgM. (31) For all studies LAT is less sensitive than ELISA, while LAT can be used for epidemiological studies (32). Using different serological tests, the variation between the results obtained depended the serological test specificity and sensitivity.

ELISA, low coast, quantitative, sensitivity, but requires standardization of the antigen used (33). The transmission and infection rates depend on several factors with toxoplasmosis in one host species to anther proximity domestic or wild host such as density of cats, ecological conditions and climatic, type of soil and type of serological test which used to determine the rate of infection (34).

\section{CONCLUSION}

The contamination of source feeds and water more effect on toxoplasmosis in camels. The movements of camels in area of pastures were extended more infected with a different toxoplasma godii strain, the prances study suggests high spreading of infection with important public health significance and economic impact, as well as who consume raw milk and meat. The difference is this study to other might be difference number of samples, type of management and using different serological techniques used to diagnosis. From this study camel toxoplasmosis is widespread in Wasit provinces.

\section{References}

1. Montoya, J.G., Remington, J.S. (2008). Management of Toxoplasma gondii infection during pregnancy. Clin. Infect. Dis., 47(4):554-66

2. Dubey, J.P., (2010). Toxoplasmosis of Animals and Humans, 2nd ed. CRC Press, Boca Raton, Florida, USA, pp. 1-313.

3. Holec-Gąsior, L., Drapała, D., Dominiak-Górski, B. and Kur, J. (2013). Epidemiological Study of Toxoplasma gondii Infection among Cattle in Northern Poland. Annals of Agricultural and Environmental Medicine, 20, 653-656.

4. Sanati, H., Fard, S.R.N., Nahrevanian, H., Khalili, M. and Safari, Z. (2012). Seroprevalence of Toxoplasma gondii Antibodies in Dairy 
5. Cows in Kerman Province, South East Iran. Current Research Journal of Biological Sciences, 4, 417-421.

6. Dubey, J.P. (2004). Toxoplasmosis - a waterborne zoonosis. Vet. Parasitol.,126 (12):57-72.

7. Johnson J, Suzuki Y, Mack D, Mui E, Estes R, David C, Skamene E, Forman J, McLeod R. (2002). Genetic analysis of influences on survival following Toxoplasma gondii infection. Int J Parasitol;32(2):179-85.

8. Edwards, J.F., Dubey, J.P., (2013). Toxoplasma gondii abortion storm in sheep on a Texas farm and isolation of mouse virulent atypical genotype T. gondii from an aborted lamb from a chronically infected ewe. Vet. Parasitol., 192, 129- 136

9. Buxton D, and Brebner J (1998). Toxoplasmosis. In: Rodolakis, A. Nettleton, P.; Benkirane, A. Editors: Manual for laboratory diagnosis of infectious abortion in small ruminants. FAO, pp. 97-109.

10. Barbosa IR, de Carvalho Xavier Holanda CM, de Andrade-Neto VF. (2009). Toxoplasmosis screening and risk factors amongst pregnant females in Natal, northeastern Brazil. Trans R Soc Trop Med Hyg.;103(4):377-82.

11. Dawo F. (2010). Mysterious mortality in camels (Camelus dromedarius) in Borana, Ethiopia: evidence of its association with reproductive age groups. Rev Sci Tech, 29:621-628.

12. Megersa B. (2010). An epidemiological study of major camel diseases in the Boran lowland, southern Ethiopia. DCG report No. 58. Oslo, Norway: Drylands Coordination Group;:1-51. http://www.drylands-group.org, accessed on November 10, 2013.

13. Moghazy, E.I., Kandil, F.M., Shaapan, R.M. (2011). Toxoplasma gondii: comparison of some serological tests for antibody detection in sera of naturally infected pigs. World J. Zool., 6(2): 204-8

14. Fayer, R. (1981).Toxoplasmosis update and public health implication. Can. Vet. J., 22: 344-352.

15. Mahmoud, Marai H. S. ; Al-Rubaie ,Abdel-Elah S.M.; Al-Jeburii, Kefah O. S. \& Taha, Abdel-Kareem A.( 2014). Serosurvillance on Toxoplasmosis in Camels (Camelus dromedarius) at Al-Najaf

16. Province Kufa Journal For Veterinary Medical Sciences Vol. (5) No. (2)

17. Latif, M. A.; Mehdi,A.J. and Rasheed,R.N. (1998). Prevalence of toxoplasma antibodies among camels in Iraq. Al-Mustansirya J. Sci.,9:40-42.

18. Al-Hindawe A J. (2006). Seroprevalence of Toxoplasmosis (Toxoplasma gondii) infection in the camels in Al-Qadisiya governorate. Al-Qadisiya Vet. Med. Sci .2:7173.

19. Al-Mudhfer S. M. and Kshash Q.H. (2012). Serological Study About Toxoplasmosis in camels . J. Al-Qadsia Agricul.Sci. 2(1):102-107.

20. Khalil K. M. and Elrayah I. E. (2011). Seroprevalence of Toxoplasma gondii Antibodies in Farm Animals (Camels, Cattle and Sheep) in Sudan. J. Med. Anim. Health, 3: 36-39.

21. Utuk A.E., Kirbas A., Babur C., Balkaya I. (2012). Detection of Toxoplasma gondii Antibodies and Some Helminthic Parasites in Camels from Nevsehir Province of Turkey. Israel J. Vet. Med., 67:106.

22. Shaapan R.M. and Khalil A.M. (2008). Evaluation of Different Toxoplasma gondii Isolates as Antigens Used in the Modified Agglutination Test for the Detection of 


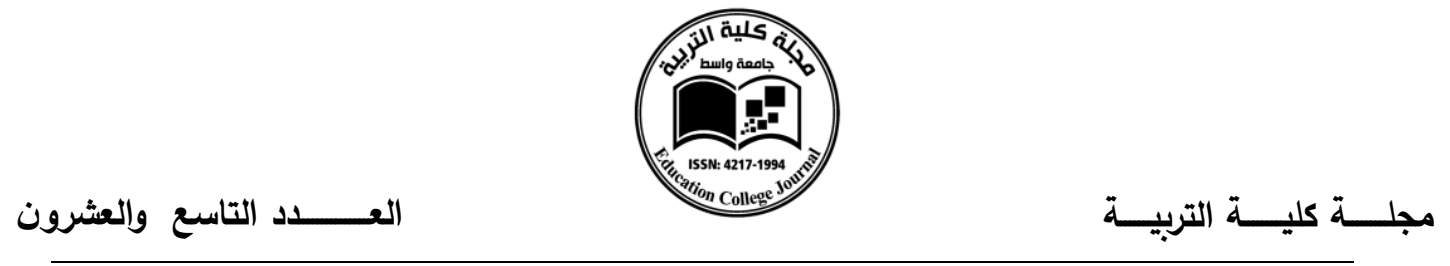

Toxoplasmosis in Camels and Donkeys. Am-Euras. J. Agric. \& Environ. Sci., 3 (6): 837-841,

23. Al-Anazi A.D. (2012). Antibodies in sera from camels(Camelus dromedarius) in western and southern regions of central province, Saudi Arabia . J. Egypt. Soc. Parasitol. 42, 3: 659 -664.

24. Sadrebazzaz A, Haddadzadeh H. , Shayan H. (2006).Seroprevalence of Neospora caninum and Toxoplasma gondii in camels (Camelus dromedarius) in Mashed, Iran. J.Parasitol. Res., 98: 600- 601.

25. Al-Anazi AD. (2011). Seroprevalence of Neospora caninum and Toxoplasma gondii antibodies in sera from camels (Camelus dromedarius) in Riyadh Province, Saudi Arabia. J. Egypt. Soc. Parasitol. 41, 2:245-50

26. Sadrebazzaz A, Haddadzadeh H., Shayan H. (2006). Seroprevalence of Neospora caninum and Toxoplasma gondii in camels (Camelus dromedarius) in Mashhed, Iran. J.Parasitol. Res., 98: 600- 601.

27. Khalil K.M. and Elrayah I.E. (2011) Seroprevalence of Toxoplasma gondii Antibodies in Farm Animals (Camels, Cattle and Sheep) in Sudan. Journal of Medicine and Animal Health, 3, 36-39.

28. Hamidinejat H., Ghorbanpour M., Rasooli A., Nouri M., Hekmatimoghaddam S., Namavari M.M. , Pourmehdi-Borojeni M. and Sazmand A. (2013). Occurrence of Anti-Toxoplasma gondii and Neospora caninum Antibodies in Camels (Camelus dromedarius) in the Center of Iran. Turkish Journal of Veterinary and Animal Sciences, 37, 277-281

29. Utuk A.E., Kirbas A., Babur C. and Balkaya I. (2012) Detection of Toxoplasma gondii Antibodies and Some Helminthic Parasites in Camels from Nevsehir Province of Turkey. Israel Journal of Veterinary Medicine, 67, 106.

30. Elamin E.A., S. Elias A. Daugschies and M. Rommel (1992). Prevalence of Toxoplasma gondii antibodies in pastoral camels (Camelus dromedarius) in the Butana plains, mid-Eastern Sudan. Vet. Parasitol., 43: 171-175.

31. Dubey J.P., Lin T.L. (1994). Acute toxoplasmosis in a gray fox (Urocyon cinereoargenteus). Vet. Parasitol., 51: 321-325.

32. Al-Husseiny S.H. (2009). An investigation of sheep toxoplasmosis in Basrah Province / Iraq. M.Sc. Thesis - College of Veterinary Medicine - University of Basrah - Iraq.

33. Zhu C. , Cui LL., Zhang LS. (2012). Comparison of a commercial ELISA with the modified agglutination test for detection of Toxoplasma gondii antibodies in sera of naturally infected dogs and cats. Iranian J Parasitol, 7:89-95.

34. Dubey, J.P., Thulliez, P.,Weigel, R.M., Andrew, D.C., Lind, P., Powell, E.C., (1995). Sensitivity and specificity of various serological tests for detection of Toxoplasma gondii infection in naturally infected sows. Am. J. Vet. Res., 56: 10301036.

35. Cook A, Gilbert R, Buffolano W, Zufferey J, Petersen E, Jennam PA, Foulon W, and Semprini (2000). A. Source of toxoplasma infection in pregnant women. European multicentre case control study. B. M.J.; 32 (15):142-174.

36. Tenter A. M. , Heckerotg A. R. and Weiss L. M. (2000). Toxoplasma gondii animals to humans. Int. J. Parasitol. 30:1217-1258. 